NBER WORKING PAPER SERIES

\title{
WATER, WATER EVERYWHERE: MUNICIPAL FINANCE AND WATER SUPPLY IN AMERICAN CITIES
}

\author{
David Cutler \\ Grant Miller \\ Working Paper 11096 \\ http://www.nber.org/papers/w11096
NATIONAL BUREAU OF ECONOMIC RESEARCH
1050 Massachusetts Avenue
Cambridge, MA 02138
January 2005

This paper was prepared for the National Bureau of Economics Research's Corruption and Reform Conference held in Salem, MA on July 30 and 31, 2004. We thank conference participants for helpful comments and suggestions. Michael Edelstein, Claudia Goldin, and Sukkoo Kim graciously made historical data available to us. Research support from National Institute on Aging grant number T32 AG00186 through the National Bureau of Economic Research (NBER) is gratefully acknowledged. All errors are our own. The views expressed herein are those of the author(s) and do not necessarily reflect the views of the National Bureau of Economic Research.

(C) 2005 by David Cutler and Grant Miller. All rights reserved. Short sections of text, not to exceed two paragraphs, may be quoted without explicit permission provided that full credit, including $\odot$ notice, is given to the source. 
Water, Water, Everywhere: Municipal Finance and Water Supply in American Cities David Cutler and Grant Miller

NBER Working Paper No. 11096

January 2005

JEL No. N4, I1, H4

\section{ABSTRACT}

The construction of municipal water systems was a major event in the history of American cities bringing relief from disease, providing resources to combat fires, attracting business investment, and promoting development generally. Although the first large-scale municipal water system in the United States was completed in 1801, many American cities lacked waterworks until the turn of the twentieth century. This paper investigates the reason for the century-long delay and the subsequent frenzy of waterworks construction from 1890 through the 1920s. We propose an explanation that emphasizes the development of local public finance. Specifically, we highlight the importance of municipal bond market growth as a facilitator of debt finance. We argue that this explanation is superior to others put forward in the literature, including disease knowledge, the presence of externalities, municipal population density, natural monopoly, contracting difficulties, corruption costs, and growth in the supply of civil engineers.

David Cutler

Department of Economics

Harvard University

Cambridge, MA 02138

and NBER

dcutler@harvard.edu

Grant Miller

NBER

1050 Massachusetts Avenue

Cambridge, MA 02138

nmiller@fas.harvard.edu 


\section{Introduction}

Samuel Taylor Coleridge wrote about an ancient mariner stranded at sea, but he might as well have been writing about nineteenth century American cities. ${ }^{1}$ Although large-scale municipal water supplies first emerged in the U.S. at the beginning of the nineteenth century, water resource development and provision in many American cities remained abysmal many decades later. A large share of households continued to rely on private wells and privies, which generally resulted in "circular water systems" that re-circulated household waste and perpetuated disease (Melosi 2000). Some larger cities and wealthier neighborhoods had initially enjoyed an escape from this vicious cycle. However, rapid urban growth, a weak understanding of disease transmission, and rudimentary sanitary engineering resulted in the deterioration of water provision and sewage removal to the point that they became large-scale circular water systems (Duffy 1990). Massive fires still wreaked havoc as early water systems failed to meet the needs of unprecedented urban growth (Anderson 1988), and corruption in water contracting was widespread (Blake 1956).

By the 1930s, however, Coleridge was definitely out of place. The scientific understanding of disease had made unprecedented strides. A large core of technocrats and municipal engineers had assumed important roles in city governments, and municipal water systems had enjoyed tremendous growth and development. Major conflagrations were no longer the scourge they had once been (Melosi 2000). Clean water technologies (filtration and chlorination) were responsible for about half of the enormous health gains in the early twentieth century - prior to the revolution of new drugs and the advent of modern medicine (Cutler and Miller 2004).

What led to this dramatic transformation of water provision? Clearly there are multiple dimensions of a "good" water system - and potentially different explanations for improvements in each. This paper focuses on radical increases in the quantity of water supplied in the late nineteenth and early twentieth centuries. ${ }^{2}$ In the case of water system expansions, at least part of the answer appears to lie with municipal ownership. Case histories of municipal water systems suggest that cities tapped new water supplies or greatly improved existing ones when private

\footnotetext{
${ }^{1}$ The title of our paper comes from the famous verse of Coleridge, "Water, water, every where/ And all the boards did shrink; / Water, water, every where, / Nor any drop to drink." The Rime of the Ancient Mariner, 1797.

${ }^{2}$ Cutler and Miller (2004) examines water quality and health.
} 
suppliers failed to perform well. Major investments in water systems coincided with the rapid rise in public ownership between 1890 and the $1920 \mathrm{~s}^{3}$

What was so unique about the public sector that led it to achieve these gains, and why did local governments suddenly get involved when they did? We discuss two major types of explanations for municipally-led improvements in water systems. The first is changes in the value (or perceived value) of water systems. The late nineteenth and early twentieth centuries were times of major advances in the understanding of disease. It is possible that the public goods nature of clean water became clear during this era. But this explanation does not seem right; the link between dirty water and disease was apparent long before the acceptance of germ theory, even if the biological mechanism underlying the link was not well understood. Alternatively, increases in the population density of cities may have increased the need for clean water as public health conditions deteriorated. However, there do not appear to have been sharp changes in population density that coincided with waterworks expansion and public ownership.

The second type of explanation is that the costs of water systems were changing. Water systems are a natural monopoly, so private firms that win contracts for them have incentives to under-provide services (and charge a high price). As cities grew, welfare losses may have also grown. We suspect this cannot be the whole explanation, however. Other utilities like the gas industry were predominantly private even though they were also natural monopolies. Contracting between the public and private sector in the era prior to municipal ownership may also have been difficult. Contracting costs between cities and private water companies were presumably rising, but the timing and pattern of public ownership across big and small cities suggests this is not the primary explanation. Private companies may have also feared expropriation by municipal authorities after making costly infrastructure investments (Troesken and Geddes 2003). However, private water companies were actually more likely to have expensive filtration plants than public ones (Troesken 1999), and no similar pattern of public ownership emerged in other utilities that required large investments. Other explanations such as reductions in corruption costs due to administrative reforms and the rise of a cadre of skilled municipal engineers also appear unsatisfactory.

We propose an alternative explanation for the rapid growth of water systems that emphasizes the costs of capital and the development in local public finance. In the late

\footnotetext{
${ }^{3}$ It is not clear that public ownership conferred other benefits such as health improvement (Troesken 1999).
} 
nineteenth century, there was enormous latent demand for the expansion of waterworks - to serve neglected neighborhoods, to find clean water for drinking, and to ensure sufficient water supplies for fighting fires. The cost of building sufficiently large water systems was also enormous. Modern water systems frequently required transporting water from far away and investing in filtration plants. These costs were too large for private firms and sufficiently large that only the largest cities or cities with access to sophisticated municipal finance techniques could afford them. ${ }^{4}$ While the largest cities invested in water systems prior to the late nineteenth century, we propose that the development of municipal bond markets was key to providing an adequate volume of water in many American cities. We present some evidence for this explanation using data on the cost of municipal water systems, the development of means of financing them, the time pattern of investment in water resources, and a time series of historical municipal bond yields.

In this paper, our approach is informal; we provide some selected trends, illustrations, and case studies to support our contention that the development of local public finance was primarily responsible for water system improvements. The second section presents a snapshot of how American cities typically addressed their water and sanitation needs before the adoption of modern water and sewage systems. The third section presents case histories of Boston and New York, suggesting that city governments intervened to provide water when existing private ones failed to perform well. The fourth section examines the development of local public finance and its importance in the construction and expansion of water systems. The fifth and sixth sections review alternative explanations for local government ownership and control of water supplies and provide evidence refuting each; the seventh section concludes.

\footnotetext{
${ }^{4}$ Early in the nineteenth century before the development of municipal finance, private companies were perhaps better suited to building water systems.
} 


\title{
A Snapshot of Municipal Water and Sewer Systems in the Late Nineteenth and Early Twentieth Centuries
}

\author{
Household Wells and Privies
}

Households not connected to municipal water and sewer systems generally provided these services for themselves by digging wells and privies on their lots. Dry privies were generally used only for human waste and were generally placed a distance from homes. Cesspools received human and other types of wet waste and were generally placed in basements or immediately adjacent to homes, into which household drainage was emptied. (The terms privy and cesspool have come to be used interchangeably.) Privies and cesspools were generally constructed by digging a hole about 3 or 4 feet in diameter and at least 5 feet deep. Cesspool overflow was very common, saturating the earth around them with filth. Privy vaults were generally lined with brick, stone, or wood. Over a period of time, vaults would rot or begin to disintegrate; even in their prime, they were porous enough to allow contaminants to escape. The common result was the tainting of nearby groundwater into which household wells generally drew (Duffy 1990, Melosi 2000).

Not all waste material made its way directly into household water supplies or the surrounding soil. In many other cases, it journeyed to the streets in front of private lots. Liquid wastes were allowed to run into the open gutters of the alleys and into the streets. Here they mixed with cesspool contents removed from privies by hand and bucket and dead animals and refuse (Duffy 1990). City governments would sporadically send horse-drawn carts through residential areas to remove the buildup of waste that collected in the streets and gutters. Removed waste known as "night soil" was used as a fertilizer through the turn of the twentieth century, when an overwhelming preponderance of scientific evidence had demonstrated such practices to be unhealthy. Cities gradually began to introduce a new suction method of emptying privies using airtight hoses and cart removal, although these services were not often provided on a sufficiently regular basis. The prevalence of cobblestone streets also exacerbated the problems of festering garbage and waste dumped onto streets. Cobblestone surfaces did not wash or drain well, and they made waste removal considerably more difficult and less effective (Duffy 1990). 


\section{The Requirements of Constructing Water Systems}

The challenges of constructing large municipal water systems were quite formidable during the nineteenth century (indeed they are not trivial today). A variety of complex decisions had to be made; each one involved extensive research and planning together with a precarious balancing act in volatile political environments. An appropriate water source had to be identified. For most cities, there were generally many candidates, including surface water (streams, rivers and lakes) and ground water sources of various sorts. Survey work by geologists and engineers was a difficult and time-consuming task, and their findings were often controversial and subject to political pressure. Each potential source required estimates of supply volume and purity (particularly difficult before science elucidated what "purity" meant). Engineers would then attempt to estimate how water from each source could be delivered to city populations. This involved acquiring water using pumps and dams, transporting it via large aqueducts, raising it to sufficient elevation to facilitate flow by means of gravity, and storing sufficient quantities of water in large city reservoirs to smooth water consumption across periods of high and low demand (Blake 1956).

With this information, each potential water source would then require rough cost estimates. Not surprisingly, these estimates were often quite inaccurate. Private interests also commonly exerted considerable influence over these estimates and surveys. In most cases, the expense of such waterworks projects were staggering regardless of the source chosen, totaling many times annual municipal revenue in some cases (Blake 1956). Given the amount of information required, the uncertainty surrounding it, the sheer size of the financial commitment, uncertainty about future city needs, and strong political pressures from various directions, it is not surprising that many decades of debate often preceded significant waterworks projects.

\section{Sanitary Problems Linked to Municipal Water and Sewer Systems}

During the 1870s and 1880s, major cities expanded or built new water and sewer, systems, instituted systematic garbage collection, and began paving cobblestone roads with smoother materials like granite and occasionally asphalt. Clearly these services -municipal 
water and sewers in particular - held promise for addressing the woes caused by household wells and privies. But their promise was not to be immediately realized.

Sanitary engineering was developing as a field during the 1870 s and 1880 s, which meant that many of the eastern cities with sewers and drains constructed in earlier years were done so in a haphazard and inadequate manner (Melosi 2000). A considerable amount of waste continued to be dumped into city streets, and these wastes were generally swept or washed down drains and into sewers. Water systems generally provided inadequate water or inadequate water pressure to wash streets and flush sewers on a regular basis. Moreover, because most sewer systems were only designed to carry storm water, they often became clogged because they lacked the sufficient capacity (many were not more than 2.5 or 3 feet in diameter) (Duffy 1990). Rapid population growth during the nineteenth century greatly exacerbated the capacity problems of existing systems and often negated the benefits of investments made to improve existing systems. In addition to a large amount of waste introduced into sewers from city streets, the advent of water closets in the US in the 1870 s added considerable strain to already overburdened sewers. The end result was often backflow from sewers into streets and gutters; some observers began referring to sewers as "elongated cesspools" (Duffy 1990).

Perhaps the worst sort of backflow was the emptying of sewer systems directly into drinking water supplies. In the late nineteenth century, the primary sewer outfalls of many American cities emptied upstream of river water intakes or directly into large water bodies (like the Great Lakes) in close proximity to water intakes. The few cities that addressed this problem early on also suffered from the dumping of untreated sewage by upstream communities. This phenomenon essentially reproduced the household circular water systems on the municipal level (Duffy 1990).

\section{Service Provision at the Household Level}

Household water and sewer connections were often poorly constructed, resulting in waste and the continued spreading of filth. Annual flat fees were paid for piped water, giving households no incentive to fix leaky connections. Not until early in the twentieth century did many cities make efforts to meter household water, charging rates per volume of water used (or wasted) rather than flat fees. Water pressure, turgidity, and taste varied greatly from moment to 
moment, and isolated reports of other irregularities emerged from time to time (for example, fish being delivered through infrastructure pipes into bathtubs). As water closets began replacing simple privies and chamber pots after 1870 , many of them resulted in more unsanitary conditions than the use of privies and cesspools. Many were not properly installed (permits to install water closets were trivial to obtain) and resulted in considerable sewage leakage (Melosi 2000).

\section{Water Systems and Fires}

The importance of water systems to combat major fires was an issue that emerged early in the nineteenth century. The growth of population and structures meant growth in the consequences of uncontrolled fires. Bucket brigades and water wagons were clearly inadequate to manage large conflagrations. In areas of cities served by water supplies, water for extinguishing fires was tapped in several ways. The most rudimentary method was to drill holes in wooden water pipes; these holes could be corked or opened as desired. A more sophisticated approach was the installation of fire hydrants. Arrangements for use of water ranged from cities paying hydrant rental fees to private water companies to water being made freely available for purposes of putting out fires. However, water pressure was inadequate to effectively combat fires with some regularity. Even in cities with well-developed water systems, they often did not extend to outlying areas, poor neighborhoods, and regions of high elevation. These areas were clearly particularly vulnerable to the destruction of fires, and fire insurance was more costly by several orders of magnitude (Anderson 1988).

\section{Public Takeovers of Private Water Systems}

Cities wishing to increase their involvement in the delivery of water essentially had two choices: build a water system if one did not exist or take control of existing private water systems. Municipal takeovers of existing private water systems generally involved either the outright purchase of private companies or the introduction of a municipal competitor to a private water company (essentially bankrupting the private company). The specifics of how this was done depended on the private company's charter. For example, if a private company had exclusive legal rights to provide water to residents of a city, these rights would generally have to 
be purchased. If a private company had exclusive legal rights to a given water source, a municipal water company could either buy this right or find another source. City governments could also petition state legislatures to revoke private water company charters under extreme circumstances.

Once a water company was municipally owned, it had to be operated. This usually required the establishment of a standing municipal water board that wasn't subject to changes with every electoral cycle (although appointment to boards was of course political), as opposed to being operated directly by a city council. Water boards would manage systems in conjunction with hired engineers and contractors. Rates would be set and collected from citizens and firms. Improvements or expansions would often begin with surveys and draft proposals prepared by engineers retained by the board. The board would decide which ones it preferred to pursue and would seek political permission and financing from the city council or other relevant municipal government authority. Once political permission was obtained and financing was approved, the water board would solicit bids for municipal contracts to actually conduct the work.

\section{The Changing Landscape of Water Provision in Subsequent Years}

The construction of water systems progressed rapidly at the end of the nineteenth century, and adequately engineered sewer systems gradually replaced the older ones designed for storm water early in the twentieth century. Near the end of the period that we examine, the 1932 federal Relief and Reconstruction Act authorized \$1.5 billion to be lent to state and local governments for public works projects; a sizeable proportion of these resources were spent on improving water and sewer systems (Melosi 2000). Not only did nearly all cities build and greatly improve water and sewer systems by this point in time, but access to them across diverse neighborhoods within cities was also greatly expanded.

The consequences of vastly improved water systems are very difficult to estimate empirically for a variety of reasons, but they undoubtedly include superior protection against fires, vast health gains, and other stimuli of economic development. The availability of water to combat fires was no longer perceived as a problem at all. Great strides in health improvement also coincided with (and appear to be driven by) water quality improvements (Cutler and Miller 
2004). In the short span of five or six decades, the sanitary environment of many American cities was transformed from one of filth to one that resembles a modern city.

\section{Case Histories of Boston and New York}

The evolution of waterworks construction and ownership was different in every city. Keeping this in mind, we present case histories of Boston and New York below. ${ }^{5}$ In both cases, waterworks were clearly used to further private interests in a variety of ways, both legitimate and otherwise. Boston and New York were reluctant to make the initial investments necessary to build water systems and preferred that private investors instead lead the way. The water supplies of both cities began with small-scale private ventures that proved to be inadequate to meet the needs of growing cities. In the end, the governments of both cities intervened to purse grander projects than private companies were willing to embrace in order to increase the available supply of water. Both examples illustrate the enormous scale of water projects.

\section{Boston}

In 1794 a group of entrepreneurs submitted a petition to the Massachusetts legislature to be incorporated to deliver water from Jamaica Pond to residents of Boston. The City of Roxbury, in which Jamaica Pond is located, opposed this proposal to no end. The following year the state legislature approved the application and incorporated The Aqueduct Corporation; the City of Boston passed a resolution approving the project as well. The company's charter gave it the right to obtain water from anywhere in Roxbury and deliver it to any part of Boston. It also contained two important restrictions: both Roxbury and Boston reserved the right to draw water for free to combat fires, and water rates were subject to court regulation.

The Aqueduct Corporation project proceeded quickly; it had obtained pine logs and awarded a contract for laying wooden pipes within months. Although historical accounts are unclear, customers appear to have been served with water by the middle of 1798. But the project failed to produce returns for its investors for 12 years. When its first dividends were paid, rates-

\footnotetext{
${ }^{5}$ Both case histories are drawn from Blake (1956).
} 
of-return were only about 1.5 percent. Business gradually improved, however, and over the next thirty years, stock in the company yielded about a 4 percent annual return.

Although successful, this first water system only served about 800 families, and its pipes were small and were too shallow, causing them to freeze during the winter. Movement toward supplying most of the city with water had its origins in a fire in 1825 that destroyed 53 houses and stores and caused half a million dollars in damage. The city council responded by beginning serious debate on how an adequate water supply for the city might be obtained. The debate would continue for nearly 25 more years.

Boston's mayor at the time, Mayor Quincy Sr., assembled a committee to investigate the matter. An engineer conducting surveys for the city reported that two sources would be most suitable: the Charles River above the falls at Watertown and Spot Pond in Stoneham. Spot Pond would not require the complications of pumping or reservoir storage because of its elevation. On the issue of ownership, the committee was split. Mayor Quincy also sought advice from the chairman of the Philadelphia Watering Committee (the success and scale of the Philadelphia waterworks was of course renowned); the chairman's answer both questioned the adequacy of the Spot Pond supply during dry months and strongly encouraged municipal ownership of any water system that Boston might pursue. On this advice, the mayor began denying petitions from entrepreneurs to establish private water company. His own efforts were frustrated as well, however, and his tenure ended without further progress.

Several years later a new mayor named Theodore Lyman again brought the water issue to the forefront - and went on record favoring municipal ownership. Jamaica Pond was clearly too small a source to serve the entire city, so new surveys were begun. These new surveys were completed in 1834 and recommended larger, more distant sources over Spot Pond and the Charles River primarily because of concerns about volume. Farm and Shakum Ponds in Framingham as well as Long Pond were touted as the most suitable alternative water sources.

Mayor Armstrong, elected in 1835, frowned upon seeking water as far away as Framingham, so he assembled yet another committee to study the matter. He also charged the committee to make a recommendation for either public or private waterworks ownership. Their report favored building a more modest system than did earlier ones, making allowances for expansion as the city's population grew rather than investing in a larger system at the outset. It promoted Spot Pond with the proviso that if this supply became inadequate, the City of Boston 
could also draw water from Mystic Pond. Interestingly, attached to the report was the charter of the Boston Hydraulic Company, which had recently been incorporated by the Massachusetts legislature but was still subject to approval by the city council. Its charter gave it the authority to take water from any source north of the Charles River within twelve miles of Boston. It also gave the city the option of purchasing a considerable share of the new company's stock. The city council approved the charter but declined to buy any of its shares.

More mayors were elected, and more committees to study how to supply the city with water were appointed. In 1837, three city commissioners were appointed to develop a concrete water supply plan for the city. It considered four of the usual suspects: Spot Pond, Mystic Pond, Long Pond, and the Charles River. The Charles River was the most unattractive of the options because it would require more mechanical pumping - and was thought to be dirtier - than the others. The real choice was essentially between Long Pond and Spot Pond (which could be supplemented with water from Mystic Pond if necessary). The three commissioners could not agree amongst themselves; two of them recommended Spot Pond, and the mayor attempted to act on it.

In 1838, what was now the standing committee on water and the city board of aldermen approved a plan to draw water from Spot Pond under municipal ownership. Not surprisingly, the two private water companies strenuously objected and even pleaded that competition between them would best serve the city's interests. Small townships around Boston also vehemently protested, fearing that local interests would be hurt and that land for the project would be seized by condemnation. Investors in the Middlesex Canal (chartered in 1793 to build a waterway connecting the Merrimac River with Boston Harbor) also protested that water flow for their canal project would be diminished. The result of these objections was a series of protracted hearings.

In 1840 Mayor Jonathan Chapman was elected, and he frowned on the city's present water initiative because of the massive outlays required in light of the rapid growth of the city's debt in recent years. As the municipal effort was halted, private efforts were reinvigorated. In 1840, the rights of the Aqueduct Corporation were expanded to include Brookline and Brighton. The company also began modest expansions of its works and replaced its wooden pipes with more durable iron ones. But it also knew that it could never supply all sections of Boston from Jamaica Pond. Fearing a municipally-owned water system, it began fostering other private interests in complementary systems that would supply other areas of the city. 
In early 1843, a member of the city council whose family owned Spot Pond for many years resigned together with colleagues to form a company to serve Boston from the pond. Several months later the Spot Pond Aqueduct Company was incorporated. The company had exclusive rights to Spot Pond, and it would provide Boston with free water to fight fires. The City of Boston was entitled to purchase up to one third of the company's stock or to seize the franchise and company property at any time at a price set by a pre-determined formula. Because of an unusual feature of the charter that made stockholders individually liable for company debts, the city decided not to purchase any shares of the Spot Pond Aqueduct Company.

In 1844 a city initiative to tap water in Long Pond (the only source now considered by the city administration to possess adequate supply for the entire city) was revived. Additional costs of supplementing Spot Pond water with Mystic Pond water reportedly made Long Pond the most appealing source in light of Boston's continued rapid population growth. The two commissioners who originally constituted a majority in favoring Spot Pond had now changed their minds; Long Pond was now the unanimous choice recommended by a new commission report. After considerable wrangling in the legislature and a few compromise amendments, in 1845 Boston was given approval by the legislature to construct a municipal water supply that tapped Long Pond. However, supporters of the private companies campaigned vigorously against it, and it was defeated by popular vote in the referendum.

The Spot Pond Aqueduct Corporation attempted to fill the vacuum, and it submitted a proposal to the city council offering to sell the city its water rights and Spot Pond itself. In considering the company's offer, the city once again reconsidered all of its options for water and once again sought outside help in assessing both the city's future water needs and the quality of each potential source. John Jervis, the chief engineer of the Croton Aqueduct Project, was chosen to conduct the new surveys. While awaiting the Jervis report, parties favoring each source were attempting to position themselves as well as possible. Promoters of Spot Pond invited members of the city council to an extravagant reception and viewing of the pond, but the viewing had precisely the opposite effect of what was intended because the pond happened to be at its lowest level for the occasion. (The small quantity of water available from Spot Pond was of course its primary drawback.) The group later claimed that the Long Pond faction had placed large stones to obstruct the flow of water into the pond at the time of the event. 
In the end, the report headed by John Jervis strongly supported the Long Pond proposal. Shortly afterwards Josiah Quincy Jr., son of the mayor who had initially explored the construction of a municipal waterworks, was elected mayor and promised to pursue water from Long Pond. Under Mayor Quincy, the City of Boston had to obtain new authority from the state legislature again to pursue its project. It was virtually unopposed (save only by the township of Lowell), and in 1846 the legislature passed a new water act. A groundbreaking ceremony marked the beginning of the project shortly afterwards. In 1848, Boston celebrated the arrival of its new water with a tremendous festival and a large fountain gushing in the center of Frog Pond in the Boston Common.

As a small side matter, there was discontent that the city's future water source had such a mundane name. A little research uncovered the pond's previous Indian name: Cochituate. Miraculously, the word's etymology was discovered to mean "an ample supply of pure and soft water, of a sufficient elevation to carry into the City of Boston, at a moderate expense" (Blake 1956). The mayor's proposal that Long Pond should subsequently be known as Lake Cochituate was enthusiastically embraced.

The completion of Boston's municipally-owned water system created obvious problems for the private companies that still existed. In late 1848 the old Aqueduct Corporation asked that the city purchase its water rights and property, pleading that the city remember that private shareholders had made great sacrifice for the public good. The mayor originally planned to offer the corporation $\$ 100,000$, but the city council knew that the old Aqueduct Corporation had no alternative but to sell its rights and property to the city. The council was therefore willing to go along with a purchase for $\$ 20,000$, a price at which the company took great offense. The city and the Aqueduct Corporation failed to reach an agreement, and the company continued serving about 400 people who preferred water from Jamaica Pond to Cochituate water. In 1851, a new city body administering the waterworks negotiated to purchase the company for $\$ 45,000$, and the company accepted the offer. This was effectively the end of private water in Boston, although some years later the city did sell the rights to supply the City of Roxbury with water from Jamaica Pond to a new private entity named the Jamaica Pond Aqueduct Corporation. 
New York

Had it not been for the impediment of the Revolutionary War, a man named Christopher Colles may have succeeded in building a water system in New York late in the eighteenth century. After the war, numerous citizen movements pressed the city council to construct waterworks for the city. In 1798, a proposal by a physician, scientist, and engineer named Joseph Browne to dam and tap water from the Bronx River was seriously entertained. However, Joseph Browne also proposed that a private entity carry the proposed project forward. The city council considered it undesirable to place a private company in such a powerful position, so it instead decided to request authority from the state legislature to build a water system itself. Through clever maneuvering of state Assemblyman Aaron Burr, however, the bill that the state legislature produced authorized a charter for a private water company instead. Ironically, it was Alexander Hamilton whose advocacy then persuaded the city council to accept the bill as produced by the state legislature. One of the main points that furthered its case was the avoidance of enormous expense and taxpayer burden.

The Manhattan Company was then quickly incorporated; its new charter placed far fewer requirements on it than did other contemporary private water company charters of the day (again, courtesy of the efforts of Aaron Burr). The charter did stipulate, however, that if the company did not provide a continuous source of "pure and wholesome" water for all citizens desiring it within ten years, it would be dissolved. The other noteworthy feature of the charter was a carefully hidden section that gave the company the legal right to use all "surplus" capital for other purposes unrelated to water.

This obscure section of the charter opened the door for Aaron Burr to pursue banking through the Manhattan Company, which had been his intention from the beginning. Bank charters of the day were difficult to obtain through protracted political processes and were limited in duration; the Manhattan Company's charter had crept into existence below the political radar and was unlimited in duration. Although some other members of the state legislature apparently knew about the scheme, there was outrage when it was publicly discovered. Burr lost his position in a subsequent election, but the company lived on despite attempts of his political adversaries to undermine it. 
To maintain its good-standing, it was clear that the Manhattan Company had to provide water to some degree. The real question remained how adequate it would be. Despite serious concerns about its purity, the company decided to tap groundwater with the use of wells and pumps. Some water was flowing as early as 1800. Ironically, Joseph Browne was the lead engineer of the project. Problems and complaints about irregular and unpredictable service began almost immediately. The quantity of water provided was also inadequate for street washing and gutter flushing, forcing the city to rely on older wells for this purpose. The company provided free water to the city to fight fires, although its adequacy is unclear.

By 1804, the city council decided that the Manhattan Company's supply was inadequate to keep pace with city growth and began revisiting other proposals to draw water from more distant sources such as the Bronx River. The company's banking business was booming, so its interest in water was waning even further. (Incidentally, by this time political and financial troubles had forced Aaron Burr to sell most of his stock in the company, and he had been removed from its board.) De Witt Clinton, mayor of New York at the time, proclaimed in 1808 that the company had not fulfilled the requirement of its charter (that it provide "pure and wholesome" water for all citizens desiring it) and thought that given the difficulties and low profitability of its water operations, it might be willing to sell its waterworks to the city. This would of course require the state legislature to amend the original charter for it to continue with its banking activities. Interestingly, De Witt Clinton was also one of the Manhattan Company bank's directors. One of the points upon which negotiations hinged was the price to be paid to the Manhattan Company to acquire its waterworks. Many on the city council believed that it operated at a loss, although its books suggested that it earned an annual return of just under 7 percent on its original investment.

With this issue unsettled, the city council made an application to the state legislature to alter the Manhattan Company's charter and to receive authority to purchase the waterworks. Amazingly enough, in addition to serving as mayor and as a bank director, De Witt Clinton was also a prominent state senator representing a southern district of New York. The legislature acquiesced to these requests. The Manhattan Company was given the right to lease or sell its waterworks and rights, the length of time it had to provide "pure and wholesome" water for all citizens desiring it was extended to 20 years, and its new charter gave it the right to continue with its banking and other activities even after divesting itself of its waterworks. Additionally, 
the charter would continue to be perpetual until the company sold the waterworks, at which point it would last for 30 years following the sale. The company therefore naturally tried to postpone the sale as long as possible.

Complaints about the company's water service were constant. Portions of the city (the ones with pipe infrastructure) received no water at all for prolonged periods of time. Repairs were made only to stave off crises of public outrage. Water availability to fight fires was so poor that public funding was used to build cisterns for collecting rain water to be used to combat fires. Fires and disease epidemics (despite a poor understanding of the basis of disease) continued to push the inadequacy of water supply to the political forefront; public opinion was squarely opposed to the service provided by the company.

In subsequent years, the alliance between the Manhattan Company and the city government deteriorated. The city was highly indebted to the bank, and to meet its obligations it eventually resorted to selling off its stock in the company. De Witt Clinton himself also slowly sold his company stock, and in 1813 he declined to be re-elected as a bank director. By 1820, De Witt Clinton was governor of New York, and both he and the state legislature supported drawing water for New York City from upland rivers. But the city council continued to be conflicted about how to proceed.

In 1823, after several years of surveys and considering its options, the city council supported another private initiative to charter the New York and Sharon Canal Company to build a waterway from Sharon, CT to the Hudson River to join with a proposed canal to be built from Sharon to the Housatonic River. The state legislature approved the measure. Another private proposal to charter the New York Waterworks Company also gained momentum, alarming both the Manhattan Company and the Sharon Canal Companies. Although its charter was eventually approved, it was believed to be flawed because the Manhattan Company held exclusive rights to groundwater under Manhattan and the Sharon Canal Company held exclusive rights to surface water in Westchester County. The Manhattan Company clearly had the most to lose because of its profitable banking activities. Although it was unwilling to invest in drawing water from distant rivers, it did begin to seek new groundwater supplies by drilling a new well and began replacing its wooden pipes with iron ones.

To add to the confusion, a new report claimed that the water supplies of Rye Pond and the Bronx River, upon which both the New York Waterworks Company and Sharon Canal 
Company projects depended, was inadequate to meet the needs of New York City. After 1830, the water demand in New York had grown so much that serious attention began shifting from the Bronx River to the Croton River. Previous consideration of the Croton was limited by the daunting expense required to reach it.

With its eye on mounting a challenge to the Manhattan company, that year the city council appointed a committee to investigate whether or not the company had the right to discontinue providing water for fire plugs at will or any obligation to pay for its damage to streets and sidewalks - and more generally, if it had met the conditions of its original charter. The committee found that water was available to only one-third of the paved and built city and that its failure to seek more copious sources was inexcusable - in short, that it had not met its obligations. An additional blow to the Manhattan Company was a communication to the city council by a body of well-known and respected doctors and chemists. It concluded that all of the groundwater in Manhattan was horribly contaminated with filth from graveyards and privies.

By 1833 it was clear that the city was going to build its own waterworks, and after a considerable amount of debate and conflicting geological surveys and engineering reports, the Croton was agreed upon as the most promising source. The Manhattan Company therefore offered to sell all of its water rights to the city, leaving the price open to negotiation. After a devastating fire in 1836 , the city opened negotiations with the company to obtain a temporary supply for fighting fires while the Croton Aqueduct was under construction. No agreement was ever reached, however. At the same time, the state legislature found that the company had violated its charter.

In the end the Manhattan Company's rights were never purchased because with the opening of the Croton Aqueduct in 1842, they were essentially not needed. The company had some legal claim to the groundwater in Manhattan, but the new source did not draw on Manhattan groundwater at all. When Croton water began flowing into the city, the company simply lost its customers. Ironically, it retained its wells for decades afterwards - not because it was actively providing water from them, but because it feared future challenges to its charter. 


\section{Municipal Finance and Public Ownership of Water Systems: History and Evidence}

In the cases of Boston and New York, city government intervened to provide water when existing private companies failed to perform well - which generally meant failure to provide a sufficient supply to meet growing water demand. But Boston and New York were pre-eminent population centers in early America that were probably not representative of the typical American city. Growth in water quantity in the typical city occurred later and coincided with the sharpest rise in public waterworks ownership. One city in which this transformation occurred after the turn of the century - New Orleans - followed a course similar to that in Boston and New York (Troesken and Geddes 2003). A private company began providing New Orleans with water in 1878 , but the company refused to extend its pipes to outlying areas of the city. Moreover, the water it did actually deliver was turgid and unfiltered. The city subsequently petitioned the Louisiana legislature to revoke the company's charter and eventually acquired the water system in 1908. Shortly afterwards the system was expanded dramatically, and filtration plants were constructed.

Figure 1 and Table 1 show that public ownership had been increasing throughout most of the nineteenth century, but that this trend accelerated from 1890 (when 43 percent of waterworks were publicly owned) through the 1920s (when 70 percent were publicly owned) - which coincides precisely with rapid growth in the number and adequacy of water systems. In particular, the period of fastest public ownership growth (ignoring the first few decades of the nineteenth century, when the absolute number of waterworks was very small) was the 1890s. Figure 2 and Table 1 show that the number of waterworks in the United States accelerated around 1890. During 1890-1900 decade, the number of miles of water mains in major cities with existing water systems also nearly doubled (Figure 3). ${ }^{6}$ This section first provides a brief overview of the development of local public finance during the nineteenth century and then presents suggestive evidence that it was the emergence of municipal bond markets that made water system improvements possible.

\footnotetext{
${ }^{6}$ This is true in major cities for which data is readily available.
} 
Local Public Finance during the Nineteenth Century

Although the precise date of the first municipal bond issuance in the United States is unknown, there were very few in the early nineteenth century. New York City issued its first securities around 1812, and bonds to support the construction of the Croton Aqueduct were issued in 1837 and 1838. Between 1830 and 1850, municipal indebtedness grew rapidly in both total and per capita terms (see Table 2 and Figure 4) - but almost exclusively in the largest cities. As Table 3 shows, at least 93 percent of all city debt on record in 1843 (the first year for which these statistics are available for all cities) was issued by major population centers (Hillhouse 1936).

The explosive growth of municipal debt in the middle of the century was probably attributable to restrictions placed on state debt. Following financial difficulties during the depression of 1837 and a series of state defaults around 1840, the landscape of local public finance changed radically. Many state legislatures amended their constitutions to prohibit state borrowing for costly canals, turnpikes, railroads, and other improvements. As states were increasingly constrained by pay-as-you-go financing, municipal debt arose to fill the gap between what could be afforded and what was thought to be needed. (Not until after World War I were many state constitutional restrictions on debt officially relaxed.) A large share of municipal debt during this period was for railroad construction. This era of expansion peaked in the late 1860s and early 1870s. Between 1868 and 1873, the net bonded debt of New York tripled; between 1867 and 1873 the bonded debt of Chicago also tripled. Debt tripled in Boston from 1868 to 1874; Cincinnati's debt grew by five times from 1868 to 1876, and Cleveland's debt grew by twelve times from 1867 to 1877 (Griffith 1974).

After these years of unchecked borrowing and spending, local economies turned sour during the panic of 1873. What ensued was the largest series of municipal bond defaults to that date. (Earlier economic slumps had caused states to default on their obligations, but municipalities generally did not have much debt during these downturns - see Grinath, Wallis, and Sylla, 1997). The number of bond issues held void rose from 35 in 1870 to 101 in 1880 (Hillhouse 1936). ${ }^{7}$ An estimated one-fifth of all municipal obligations could not be met following this depression; many of these municipal defaults during the 1870 s were associated

\footnotetext{
${ }^{7}$ Data on the total number of bond issues in these years is not readily available.
} 
with railroads. The panic of 1873 and its ensuing debt problems were especially severe in southern cities struggling under Reconstruction. Some renegotiated their debt, while others gave up their charters or went into receivership (Griffith 1974).

Following the panic of 1873 and unprecedented revelations of widespread government corruption, many states and cities introduced new municipal debt limitations as a percentage of total property assessments. New York's bonded debt peaked in 1876 and fell by a quarter during the next decade (Teaford 1984). Other cities followed a similar pattern. Strikingly, Detroit's net debt fell from $\$ 961,000$ in 1875 to $\$ 12,000$ in 1885 (Teaford 1984). In subsequent years, however, these restrictions were circumvented in several ways. One was the passage of state constitutional amendments that one historian attributes to the municipal capture of state legislatures (Teaford 1984). These amendments allowed exceptions for a variety of special ventures including "self-supporting" municipal enterprises like waterworks (Griffith 1974). Another was the creation of special districts that were not technically a part of city government. Many local water authorities were incorporated in this way to be exempt from debt restrictions (Monkkonen 1995).

The panic of 1893 also contributed to the development of municipal bond markets and their ability to fund public waterworks. Businesses were hit the hardest, while municipal governments suffered less (Griffith 1974). Consequently, municipal bonds became relatively more attractive to investors. Interest rates fell, and cities were able to borrow large amounts to continue financing their growth. To quote one financial historian, "[m]unicipalities never enjoyed such a favorable market for their securities, for by the 1890s no investment was as sound as a municipal bond" (Teaford 1984). The granting of "home rule" to city governments by state legislatures also broadened their ability to borrow and spend. However, very little of this occurred before the turn of the century (Griffith 1974).

\section{Evidence on Local Public Finance and the Supply of Water}

One explanation for rapid water system expansion at the end of the nineteenth and beginning of the twentieth centuries is the development and growing sophistication of local public finance. Private water companies could not afford to build systems to serve entire municipal populations. Only the largest cities could afford adequate water supplies until the 
means for substantial borrowing were developed. Waterworks were exorbitantly expensive, even in comparison with other municipal utilities. In 1915, the mean value of municipal waterworks exceeded annual city government revenue, as shown in Table 4. Mindful of the fact that many water systems were built long before 1915, the expenses of constructing a water system relative to annual municipal receipts were undoubtedly larger than shown here.

Available statistics suggest that in 1905, waterworks were the largest debt line item of municipal government (US Bureau of the Census 1907).

Several different strands of evidence support this view. The timing of municipal investments in water provision by city size provides a first piece of evidence. Figure 5 shows municipal ownership over time by city size among all cities with publicly-owned water systems in 1915. In general, large cities municipalized their waterworks earlier than smaller ones. For example, all of these cities with over 500,000 people in 1915 had a public water system by the end of the 1850s, while the share of smaller cities with public water systems at that time was below 20 percent. $^{8}$

If the municipal finance explanation were correct, one would also expect to see rapid growth in debt and revenue among small cities relative to large cities at the end of the nineteenth century (when Figure 5 suggests that public ownership was rising faster among the smaller cities). Figures 6 and 7 show that this is exactly what occurred. In the period from 1880 to 1902, debt in small cities grew by about one-third while debt in the largest cities fell by more than 10 percent. ${ }^{9}$

Of course this growth in municipal debt could have been due to either supply or demand factors. Our supply-side explanation is that financial innovation and investor interest made it possible for smaller cities to borrow much more at this time than earlier. Alternatively, it may have been that cities suddenly decided that they needed to borrow more and thus demanded additional debt. Although not readily available by city size, municipal bond yields during the late nineteenth century provide some means of distinguishing between supply and demand explanations for growth in municipal debt. The supply explanation implies that yields should

\footnotetext{
${ }^{8}$ It is possible that city size responded to public investments in water, but readily available statistics do not allow for the bi-directionality of this relationship to be disentangled. See subsequent paragraphs for further discussion.

${ }^{9}$ The cities used to construct Figures 6 and 7 were selected as follows. First, states with major population centers were chosen: California, Connecticut, Georgia, Illinois, Indiana, Kentucky, Louisiana, Maryland, Massachusetts, Michigan, Minnesota, Missouri, Nebraska, New Jersey, New York, Ohio, Pennsylvania, Rhode Island, Tennessee, Texas, and Wisconsin. All cities with a population of 15,000 or more in 1900 and with debt statistics in 1880, 1890, and 1902 were then chosen within these states.
} 
have fallen with the increase in borrowing, while the demand explanation implies that yields should have increased.

Figure 8 shows mean nominal and real municipal bond yields in New England from 1857

to $1913 .{ }^{10}$ In general, real bond yield fluctuations coincided with the business cycle. Real yields rose and then fell dramatically following the panic of 1873 and did not return to this level by the end of the century. Although there was a smaller increase in the middle of the 1890s, this is presumably related to the panic of 1893 . With the exception of business cycle fluctuations, real yields were low during the late 1890s and early twentieth century as municipal borrowing increased and municipal involvement in water accelerated. Lower yields during this period are generally consistent with a supply-side explanation that emphasizes the development of municipal bond markets. Evidence on alternative demand-oriented explanations is examined in the next section, but these factors should be reflected in the time series of municipal bond yields as well. The absence of high and rising real yields during this period of growing debt and increasing public involvement in water does not support them.

The decline in municipal ownership of water systems in the 1880s also lends some support to the municipal finance view. In the wake of the depression of 1873 , the corruption scandals exposed at roughly the same time, and the subsequent rise in municipal bond issues held void, borrowing declined in all cities (shown in Figures 6 and 7 for 1880 to 1890) as states imposed tight restrictions on municipal indebtedness. Although these indebtedness restrictions were only temporary obstacles, they were accompanied by the only decline in public waterworks ownership during the entire nineteenth century (see the decline from 1880 to 1890 shown in Figure 1).

\section{Alternative Explanations: Changes in Value (or Perceived Value)}

One set of alternative explanations for the rapid expansion of water systems and increase in municipal ownership is that the value (or perceived value) of water systems increased. This

\footnotetext{
${ }^{10}$ Nominal municipal bond yields shown in Figure 8 are taken from Macaulay (1938) and can also be found in NBER's Macro History Data Series \#13020. Real bond yields were calculated using the implicit GNP deflator provided in Balke and Gordon (1989).
} 
would have increased demand for water services, and particularly in the presence of positive externalities, local governments may have been the appropriate providers of water.

\section{Externalities and New Knowledge about Disease}

There are clearly large external benefits of water supplies not captured by private water companies. The most obvious ones are disease reduction and improved capabilities of combating fires (a less-clear one is that water systems were an economic stimulus through other pathways). On the surface, it is unclear why the existence of externalities would explain a sharp rise in municipal waterworks ownership beginning around 1890. Fires and epidemic infectious diseases had been serious problems in cities for as long as cities have existed. It is possible, however, that the bacteriological revolution of the 1870 s and 1880 s may have provided a new impetus for concerns about disease externalities. As knowledge of the basis of waterborne diseases became clearer, concerns about the socially-inefficient incentives of private companies may have intensified.

But there are several reasons that call this line of reasoning into question. One is that dirty water was believed to be causally linked to disease long before the bacteriological revolution. The first demonstration of the link between unclean water and disease was John Snow's famous demonstration of how cholera spread from a single water pump in London in the 1850s. Snow had premonitions of the germ theory, but it took several more decades for the theory to be fully articulated.

The prevailing theory at the time, the miasma theory of disease, held that a variety of illnesses are the result of poisonous, malevolent vapors ("miasmas") that are offensive to the smell (Anderson 1984, Duffy 1990). The widespread acceptance of the miasma theory might have been based on Pavlovian learning. People exposed to foul odors were more likely to get sick, foul-smelling areas tended to have more sick people, and more people seemed to get sick during the summer seasons during which offensive odors were more common. The leap of logic from correlation to causation led to misdirected sanitary interventions - and some successful ones as well.

The externality argument is also generally difficult to reconcile with the empirical observation that private water companies were more likely to possess expensive water filtration 
plants than were publicly-owned companies early in the twentieth century (Troesken and Geddes 2003). And private water companies were ostensibly legally liable for damages attributable to large waterborne disease outbreaks (Troesken and Geddes 2003), although it is not clear how enforceable this liability was in practice.

\section{Population Density}

As large numbers of Americans migrated to urban areas from the countryside, the population density of cities may have increased. Urban slums certainly emerged in the late nineteenth and early twentieth centuries. If the population density of cities grew rapidly, deteriorating public health conditions may have increased the demand for water. Similarly, the positive externalities of municipal water systems may have grown, giving local governments stronger reasons for getting involved.

Although reliable statistics on municipal population density before the 1890s are generally not available, there appears to have been no abrupt increase that coincided with water system growth. Data from a consistent panel of 119 cities from 1890 to 1950 suggests that the only large increase in municipal population density occurred between 1910 and 1920 (Kim 2002) - 20 to 30 years after major waterworks improvements began.

\section{Alternative Explanations: Changes in Costs}

\section{Natural Monopoly}

The cost structure of public utility provision is generally characterized by declining marginal costs. Hence, one firm could in principle serve an entire market most efficiently. Monopoly power held by a profit-maximizing firm of course commonly leads to inefficient service provision. As will all monopolists, a monopoly water supplier will raise prices to the profit-maximizing level and will restrict quantity to support those prices. Public ownership may be the natural response in the view of local governments. 
However, a natural monopoly explanation fails to account for either the timing of the increase in municipal waterworks ownership or for why waterworks were increasingly cityowned while gas and electrical utilities were not. On the timing, it is not clear why either welfare losses or local government losses should have suddenly accelerated around 1890, producing the observed increase in municipal waterworks ownership. Additionally, the cost structures of gas and electricity provision were similar, but these utilities were rarely privatized. Table 5 shows that gas companies were almost exclusively private from 1890 to 1920 when public waterworks ownership was rising most rapidly. Fewer statistics for electric companies are available, but around the turn of the century, nearly 70 percent of the 952 electric companies in the United States were privately owned (U.S. Commissioner of Labor 1899).

\section{Contracting Failures}

Although some dimensions of water provision can easily be observed and monitored, or stipulated ex ante in a contract (e.g., water pressure, rates, etc.), many others cannot. For example, it is difficult to specify in advance that certain new population centers not yet in existence should be served or what new water sources should be tapped to meet future demand growth. As the provision of water became increasingly complex and regulatory requirements became more onerous, contracting costs may have reduced the profitability of the water business, making it less attractive to private firms.

There are some suggestive findings that litigation against private water companies was positively related to municipal take-over during the period of rapid waterworks municipalization (Troesken and Geddes 2003). It is unclear why contract incompleteness would have become more problematic at the end of the nineteenth century, but there is some historical suggestion that contracts became more elaborate - and potentially more costly - shortly before 1900 . For example, the National Municipal League's model Municipal Corporation Act was drafted in 1899 and subsequently adopted by many cities (Webber and Wildavsky 1986). However, a contracting cost explanation does not square with the continuation of predominantly private ownership in gas and electricity.

Hold-up is another potential contracting difficulty. City governments may have had difficulty credibly committing not to expropriate the enormous infrastructure investments made 
by private water companies. Following the bacteriological revolution as technological innovations to combat waterborne disease were developed (such as filtration), the investments required to build and operate water systems increased substantially. Hence losses (or fears of losses) due to municipal expropriation could have potentially grown near at the end of the nineteenth and beginning of the twentieth centuries.

There is some evidence that municipal takeovers of private water systems were positively related to the extensiveness of a water system and negatively related to financial difficulties of private water companies (Troesken and Geddes 2003). One interpretation of this correlation is that cities were more likely to seize private waterworks that promised greater rents. Fear of expropriation could have also induced private companies to rationally under-invest in their water systems, resulting in inadequate service provision and an additional rationale for municipal ownership.

Countering this hypothesis is the fact that private water companies were more likely than public ones to own expensive filtration facilities. According to an 1899 federal government survey of water companies, 19 percent of the private companies had filters while only 6 percent of the public ones did (Troesken 1999). It is also unclear why municipal seizures or fear of expropriation would have risen in the 1890s and early twentieth century if it was truly a period in which corruption in municipal government was actually falling while contracts were growing more sophisticated. Moreover, the absence of municipal takeovers of other public utilities (gas and electricity) during this period also seems to contradict this view.

Finally, a recent analysis cites a positive cross-sectional correlation between population density and public ownership as evidence that contract evasion and appropriation problems were responsible for municipal control (Masten 2004). However, this would also be consistent with larger cities (which were typically denser) having greater financial means to build or expand municipal water systems.

\section{Corruption Costs and Administrative Reform}

Administrative reform that began at the very end of the nineteenth century may have reduced the corruption costs associated with municipal ownership of waterworks. As a number of city government scandals were exposed in the 1870s, cities began experimenting with 
administrative reforms that aimed to reduce corruption. These reforms appear to have been at least partially responsible for the creation of standing boards to perform specialized functions like operating water systems. Board members were surely corruptible, but probably less so than city council members (who operated municipal water systems before professional boards emerged). It is not clear if delegation of authority to city boards was actually purposeful (to reduce corruption) or coincidental (driven by the increasingly technical and complex nature of city functions).

The problem with a corruption costs and administrative reform explanation is that the sharpest rise in public waterworks ownership occurred in the 1890s. Much of the effective administrative reforms came in the early decades of the twentieth century at the dawn of the Progressive Era. This was a primary objective of the National Municipal League's model Municipal Corporation Act that was first drafted in 1899 (Webber and Wildavsky 1986). Although corruption was surely present in historical water supply and management (McCarthy 1987), it seems to have relatively little direct bearing on public ownership or the expansion of water systems.

\section{Growth in the Supply of Municipal Engineers}

A final possibility is that exogenous growth in the supply of municipal engineers made it possible for cities to operate water systems on their own. City governments may have desired to do so much earlier (either out of self-interest or public interest), but they simply lacked the human resources to do so.

The primary piece of evidence against this explanation is the fact that the public sector was in large part responsible for engineering and applied science training in the late nineteenth century. This means that increases in the number of engineers were probably not exogenous with respect to major public works projects. ${ }^{11}$ The Morrill Land Grant Act provided large tracts of federal land to states to endow and support institutions of higher education specializing in agriculture and mechanical arts (Goldin and Katz 1999). During the 1870s and 1880s, the largest

\footnotetext{
${ }^{11}$ An exogenous increase in the supply of engineers that accelerated the construction of waterworks would also be reflected in rising municipal bond yields as cities demanded additional debt. Figure 8 shows no clear evidence of this.
} 
number of new engineering programs were established at land grant institutions (Edelstein 2002).

Historical data on the output of new engineers in the United States by area of specialization are not readily available. Data on the output of civil engineers in New York State (shown in Table 6) suggests that the largest surge in the production of engineers occurred after the turn of the twentieth century. If the training of engineers in New York over time is representative of the national trend, growth in the supply of engineers does not hold much promise for explaining the rapid expansion and increasing public ownership of waterworks. ${ }^{12}$

\section{Conclusion}

The quantity of piped water supplied in American cities grew dramatically near the turn of the twentieth century, and local government ownership seems to have been a driving force behind this surge in water system construction and expansion. Governments may have wanted to be involved earlier - and in fact were in the largest cities - but financial constraints appear to have prevented them from doing so. As innovation in local public finance made it easier for smaller cities to borrow, many American cities did in fact purchase or build waterworks. Even larger cities that already owned water systems were able to finance massive expansions to previously unserved neighborhoods. In an era of rampant corruption in local government (Steffens 1957), it is striking that government involvement in such a costly sector as water seems to have advanced the public interest considerably (if not the private interests of politicians as well). This observation is consistent with those of others that corruption - although undesirable and inefficient - can in fact go hand-in-hand with policies that improve public welfare as corrupt politicians seek both political support and a robust economy to exploit (Menes 2003).

\footnotetext{
${ }^{12}$ New York State most likely led many of the other states.
} 


\section{References}

Anderson, Letty. 1984. "Hard Choices: Supplying Water to New England Towns." Journal of Interdisciplinary History 15, no. 2: 211-234.

Anderson, Letty. 1988. "Fire and Disease: The Development of Water Supply Systems in New England, 1870-1900." In Joel Tarr and Gabriel Dupuy (eds.), Technology and the Rise of the Networked City in Europe and America. Philadelphia, PA: Temple University Press.

Baker, M. N. 1948. The Quest for Pure Water: The History of Water Purification from the Earliest Records to the Twentieth Century. New York, NY: The American Water Works Association.

Balke, Nathan S. and Robert J. Gordon. 1989. "The Estimation of Prewar Gross National Product: Methodology and New Evidence." Journal of Political Economy 97, no. 1: 38-92.

Blake, Nelson Manfred. 1956. Water for the Cities: A History of the Urban Water Supply Problem in the United States. Syracuse, NY: Syracuse University Press.

Bordo, Michael and William G. Dewald. 2001. "Bond Market Inflation Expectations in Industrial Countries: Historical Comparisons.” NBER Working Paper \#8582.

Bordo, Michael and Anna Schwartz. 1997. "Monetary Policy Regimes and Economic Performance: The Historical Record." NBER Working Paper \#6201.

Carter, Susan, Scott Gartner, Michael Haines, Alan Olmstead, Richard Sutch, and Gavin Wright, eds. 2005 (forthcoming). Historical Statistics of the United States: Millennial Edition. New York: Cambridge University Press.

Cutler, David and Grant Miller. 2004. “The Role of Public Health Improvements in Health Advances: The $20^{\text {th }}$ Century United States.” NBER Working Paper \#10511.

Duffy, John. 1990. The Sanitarians. Urbana and Chicago, IL: University of Illinois Press.

Edelstein, Michael. 2002. "The Production of Engineers in New York Colleges and Universities, 1800-1950: Some New Data." Unpublished manuscript, City University of New York.

Galishoff, Stuart. 1980. "Triumph and Failure: The American Response to the Urban Water Supply Problem, 1860-1923." In Martin Melosi (ed.), Pollution and Reform in American Cities, 1870-1930. Austin, TX and London: University of Texas Press.

Goldin, Claudia and Lawrence F. Katz. 1998. "The Shaping of Higher Education: The Formative Years in the United States, 1890 to 1940.” NBER Working Paper \#6537. 
Goldin, Claudia and Lawrence F. Katz. 1999. "The Shaping of Higher Education: The Formative Years in the United States, 1890 to 1940." Journal of Economic Perspectives 13, no.1: 37-62.

Griffith, Ernest S. 1974. A History of American City Government: The Conspicuous Failure, 1870-1900. New York, NY: Praeger Publishers.

Grinath, Arthur, John Wallis, and Richard Sylla. 1997. "Debt, Default, and Revenue Structure." NBER Historical Working Paper \#97.

Hillhouse, A. M. 1936. Municipal Bonds: A Century of Experience. New York, NY: PrenticeHall.

Kim, Sukkoo. 2002. "The Reconstruction of the American Urban Landscape in the Twentieth Century." NBER Working Paper \#8857.

Macaulay, F. R. 1938. The Movements of Interest Rates, Bond Yields, and Stock Prices in the United States since 1856. New York: National Bureau of Economic Research.

Masten, Scott E. 2004. "Public Utility Ownership in 19th Century America: The 'Aberrant' Case of Water." Mimeo, University of Michigan Business School.

McCarthy, Michael P. 1987. Typhoid and the Politics of Public Health in Nineteenth Century Philadelphia. Philadelphia, PA: American Philosophical Society.

Melosi, Martin. 2000. The Sanitary City: Urban Infrastructure in America from Colonial Times to the Present. Baltimore, MD and London: The Johns Hopkins University Press.

Menes, Rebecca. 2003. "Corruption in Cities: Graft and Politics in American Cities at the Turn of the Twentieth Century." NBER Working Paper \#9990.

Monkkonen, Eric H. 1995. The Local State: Public Money and American Cities. Stanford, CA: Stanford University Press.

Steffens, L. 1957. The Shame of the Cities. Reprint, New York, NY: Hill and Wang.

Teaford, J. 1984. The Unheralded Triumph: City Government in America, 1870-1900. Baltimore, MD: Johns Hopkins University Press.

Troesken, Werner. 1997. "The Sources of Public Ownership: Historical Evidence from the Gas Industry." Journal of Law, Economics, and Organization 13, no. 1: 1-25.

Troesken, Werner. 1999. "Typhoid Rates and the Public Acquisition of Private Waterworks, 1880-1920." The Journal of Economic History 59, no. 4: 927-948. 
Troesken, Werner and Rick Geddes. 2003. "Municipalizing American Waterworks, 18971915." Journal of Law, Economics, and Organization 19, no. 2: 373-400.

United States Bureau of the Census. 1907. Statistics of Cities Having a Population over 30,000: 1905 (Special Reports). Washington, DC: United States Government Printing Office.

United States Bureau of the Census. 1907b. Wealth, Debt, and Taxation. Washington, DC: United States Government Printing Office.

United States Bureau of the Census. 1975. Historical Statistics of the United States: Colonial Times to 1970, Part 2. Washington, D.C.: United States Government Printing Office.

United States Commissioner of Labor. 1899. Water, Gas, and Electric-Light Plants Under Private and Municipal Ownership. Washington, D.C.: United States Government Printing Office.

Webber, Carolyn and Aaron Wildavsky. 1986. A History of Taxation and Expenditure in the Western World. New York, NY: Simon and Schuster. 
TABLE 1

The Evolution of Waterworks and Municipal Ownership in American Cities, 1830 to 1924

Number of Waterworks

\begin{tabular}{|c|c|c|c|c|}
\hline Year & Total & Public & Private & Percent Public \\
\hline 1830 & 45 & 9 & 36 & 20 \\
\hline 1840 & 65 & 23 & 42 & 35 \\
\hline 1850 & 84 & 33 & 51 & 39 \\
\hline 1860 & 137 & 57 & 80 & 42 \\
\hline 1870 & 244 & 116 & 128 & 48 \\
\hline 1880 & 599 & 293 & 306 & 49 \\
\hline 1890 & 1,879 & 806 & 1,073 & 43 \\
\hline 1896 & 3,180 & 1,690 & 1,490 & 53 \\
\hline 1924 & 9,850 & 6,900 & 2,950 & 70 \\
\hline
\end{tabular}

Mean Annual Change

\begin{tabular}{ccccc}
\hline \hline Period & Total & Public & Private & Percent Public \\
\cline { 2 - 3 } $1830-1840$ & 2.0 & 1.4 & 0.6 & 1.54 \\
$1840-1850$ & 1.9 & 1.0 & 0.9 & 0.39 \\
$1850-1860$ & 5.3 & 2.4 & 2.9 & 0.23 \\
$1860-1870$ & 10.7 & 5.9 & 4.8 & 0.59 \\
$1870-1880$ & 35.5 & 17.7 & 17.8 & 0.14 \\
$1880-1890$ & 128.0 & 51.3 & 76.7 & -0.60 \\
$1890-1896$ & 216.8 & 147.3 & 69.5 & 1.71 \\
$1896-1924$ & 238.2 & 186.1 & 52.1 & 0.60 \\
\hline \hline
\end{tabular}

Sources: Galishoff (1980), Melosi (2000) 
TABLE 2

Growth of Real Municipal Debt, 1843 to 1932 (in 2000 Dollars)

\begin{tabular}{cccccc}
\hline \hline Year & Total Municipal Debt (Millions) & Change & & Per Capita Municipal Debt & Change \\
\cline { 2 - 3 } \cline { 5 - 6 } 1843 & $\$ 625$ & -- & & $\$ 265$ & -- \\
1853 & $\$ 4,208$ & $\$ 3,582$ & & $\$ 963$ & $\$ 699$ \\
1860 & $\$ 4,055$ & $-\$ 152$ & & $\$ 652$ & $-\$ 311$ \\
1870 & $\$ 6,629$ & $\$ 2,574$ & & $\$ 669$ & $\$ 17$ \\
1880 & $\$ 13,547$ & $\$ 6,917$ & & $\$ 959$ & $\$ 289$ \\
1890 & $\$ 17,126$ & $\$ 3,579$ & & $\$ 775$ & $-\$ 184$ \\
1902 & $\$ 31,899$ & $\$ 14,773$ & & $\$ 979$ & $\$ 204$ \\
1912 & $\$ 60,310$ & $\$ 28,412$ & & $\$ 1,355$ & $\$ 376$ \\
1922 & $\$ 77,678$ & $\$ 17,368$ & & $\$ 1,357$ & $\$ 2$ \\
1932 & $\$ 186,924$ & $\$ 109,245$ & & $\$ 2,660$ & $\$ 1,303$ \\
\hline \hline
\end{tabular}

Sources: Hillhouse (1936), Carter et. al. (2005), and authors' calculations 
TABLE 3

Debt in Selected Cities, January 1843 (in 2000 Dollars)

\begin{tabular}{lcc}
\hline \hline \multicolumn{1}{c}{ City } & & Debt \\
\cline { 1 - 1 } New York, NY & & $\$ 295,922,345$ \\
Philadelphia, PA & & $\$ 70,915,707$ \\
New Orleans, LA & & $\$ 39,982,622$ \\
Boston, MA & & $\$ 33,757,045$ \\
Baltimore, MD & & $\$ 29,989,809$ \\
Cincinnati, OH & & $\$ 25,927,297$ \\
Charleston, SC & & $\$ 24,097,285$ \\
Savannah, GA & & $\$ 12,445,467$ \\
Mobile, AL & & $\$ 11,667,284$ \\
Albany, NY & & $\$ 9,909,959$ \\
Troy, NY & & $\$ 8,210,311$ \\
Detroit, MI & $\$ 5,424,264$ \\
Nashville, TN & & $\$ 2,642,424$ \\
Rochester, NY & & $\$ 2,228,838$ \\
Buffalo, NY & & $\$ 1,466,939$ \\
Vicksburg, MS & $\$ 1,137,162$ \\
Providence, RI & $\$ 507,652$ \\
All Other Cities & \\
\hline \hline
\end{tabular}

Sources: Hillhouse (1936), Carter et. al. (2005), and authors' calculations 
TABLE 4

The Value of Water Systems and Annual Revenue in Selected American Cities, 1915 (in 1915 dollars)

\begin{tabular}{|c|c|c|c|}
\hline & Value of Water System & Total Municipal Revenue & Value/Revenue \\
\hline All Cities Over 500,000 & $\$ 569,727,688$ & $\$ 462,077,044$ & 1.23 \\
\hline New York & $\$ 350,004,152$ & $\$ 206,010,937$ & 1.70 \\
\hline Chicago & $\$ 52,557,484$ & $\$ 80,622,887$ & 0.65 \\
\hline Philadelphia & $\$ 30,000,000$ & $\$ 45,242,379$ & 0.66 \\
\hline All Cities $300,000-500,000$ & $\$ 149,222,136$ & $\$ 146,467,942$ & 1.02 \\
\hline Buffalo & $\$ 15,702,219$ & $\$ 15,184,834$ & 1.03 \\
\hline Los Angeles & $\$ 36,058,144$ & $\$ 24,405,199$ & 1.48 \\
\hline Cincinatti & $\$ 17,366,561$ & $\$ 13,785,166$ & 1.26 \\
\hline All Cities 100,000 - 300,000 & $\$ 186,574,699$ & $\$ 171,787,677$ & 1.09 \\
\hline Jersey City & $\$ 12,448,453$ & $\$ 6,792,713$ & 1.83 \\
\hline Kansas City & $\$ 8,967,124$ & $\$ 10,296,283$ & 0.87 \\
\hline Rochester & $\$ 9,768,056$ & $\$ 7,408,794$ & 1.32 \\
\hline All Cities 50,000 - 100,000 & $\$ 93,665,860$ & $\$ 89,950,262$ & 1.04 \\
\hline Ft. Worth & $\$ 3,937,893$ & $\$ 1,694,390$ & 2.32 \\
\hline Somerville & $\$ 1,017,365$ & $\$ 1,916,006$ & 0.53 \\
\hline Harrisburg & $\$ 2,487,150$ & $\$ 1,481,848$ & 1.68 \\
\hline
\end{tabular}

Sources: US Bureau of the Census (1907), US Bureau of the Census (1975) 
TABLE 5

Public Ownership of Gas Companies, 1890 to 1920

\begin{tabular}{cccc}
\hline \hline Year & Number of Companies & Number Publicly Owned & Percent Publicly Owned \\
\cline { 2 - 3 } 1890 & 871 & 8 & 0.9 \\
1900 & 896 & 15 & 1.7 \\
1910 & 1282 & 122 & 9.5 \\
1920 & 1008 & 45 & 4.5 \\
\hline \hline
\end{tabular}

Source: Troesken (1997) 
TABLE 6

First Civil Engineering Degrees in New York State by Decade, 1830-1949

\begin{tabular}{ccc} 
Decade & Number of Civil Engineering Degrees & Change \\
\hline \hline $1830-39$ & 61 & -- \\
$1840-49$ & 88 & 27 \\
$1850-59$ & 124 & 36 \\
$1860-69$ & 523 & 399 \\
$1870-79$ & 605 & 82 \\
$1880-89$ & 712 & 107 \\
$1890-99$ & 973 & 261 \\
$1900-09$ & 2,001 & 1,028 \\
$1910-19$ & 3,330 & 1,329 \\
$1920-29$ & 2,446 & -884 \\
$1930-39$ & 3,026 & 580 \\
$1940-49$ & 2,760 & -266 \\
\hline \hline
\end{tabular}

Source: Edelstein (2002) 
Figure 1: Public Waterworks Ownership In American Cities During the Nineteenth and Early Twentieth Centuries

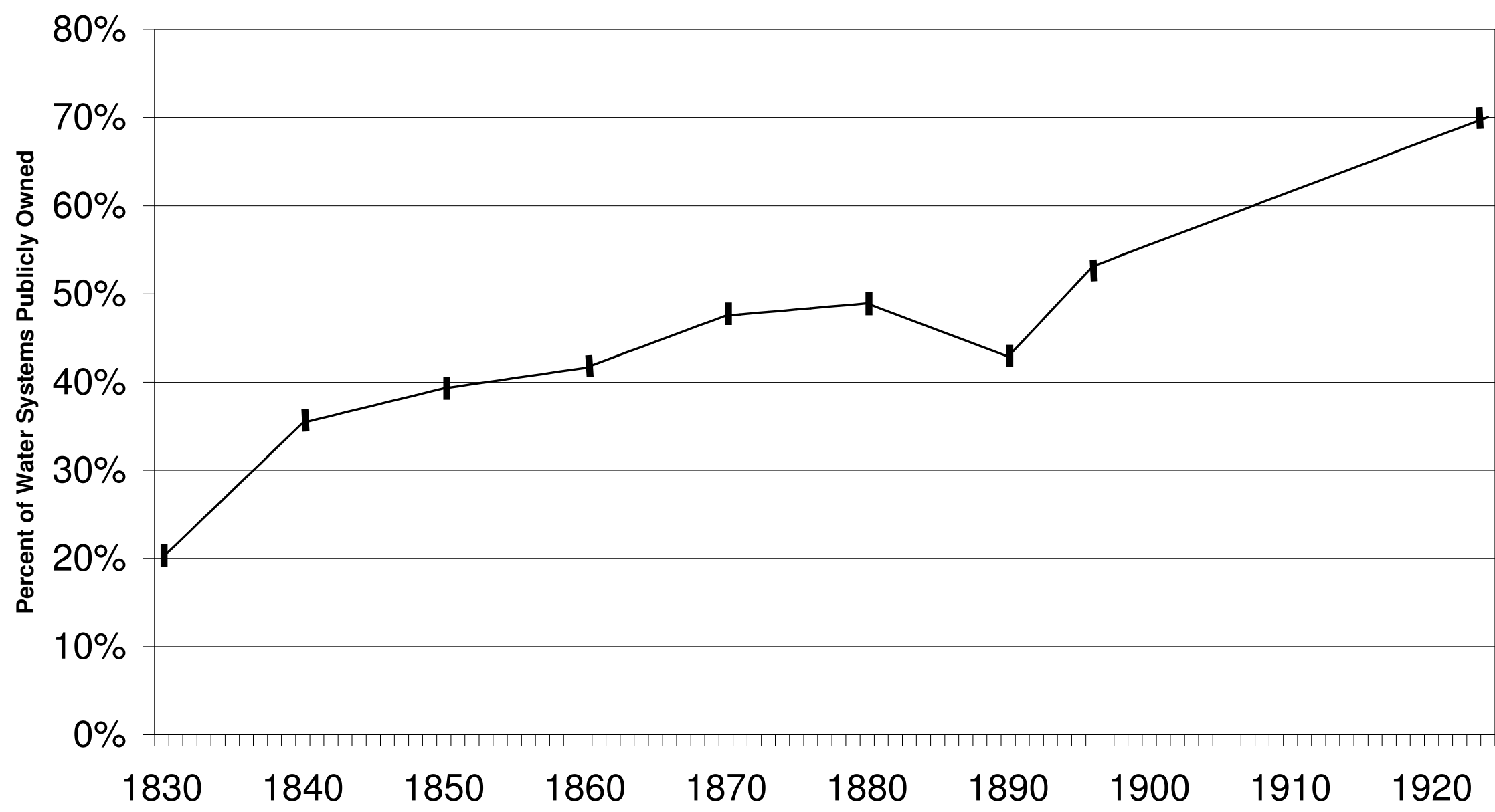

Note: Data available on the decade from 1830 to 1890 and for 1896 and 1924; all points in between are obtained by linear interpolation Sources: Galishoff (1980), Melosi (2000) 
Figure 2: Number of Municipal Water Systems in the United States, 1830-1924

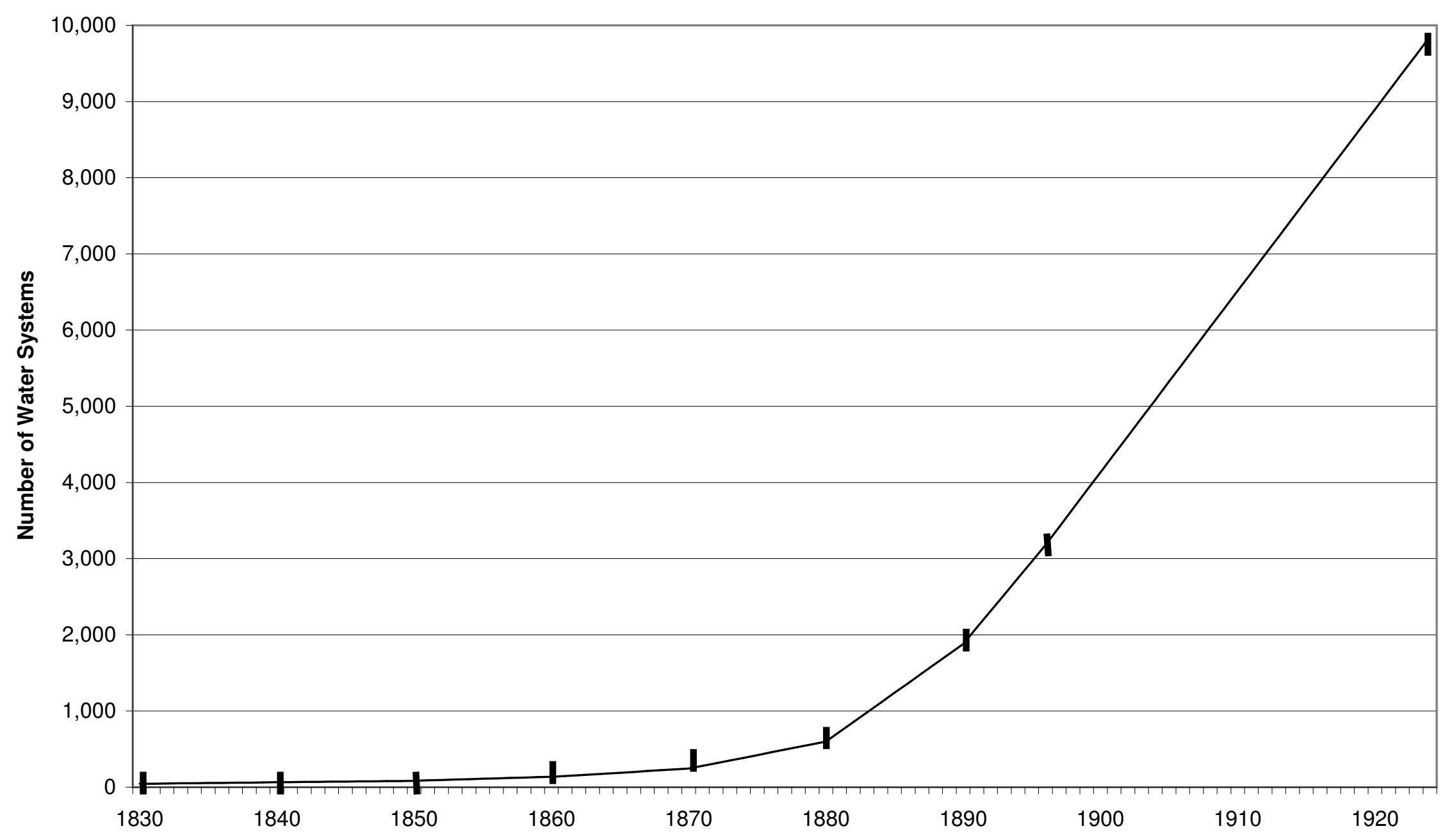

Note: Data available on the decade from 1830 to 1890 and for 1896 and 1924; all points in between are obtained by linear interpolation Source: Melosi (2000) 
Figure 3: Water System Growth in Selected Cities from 1889-92 to 1902

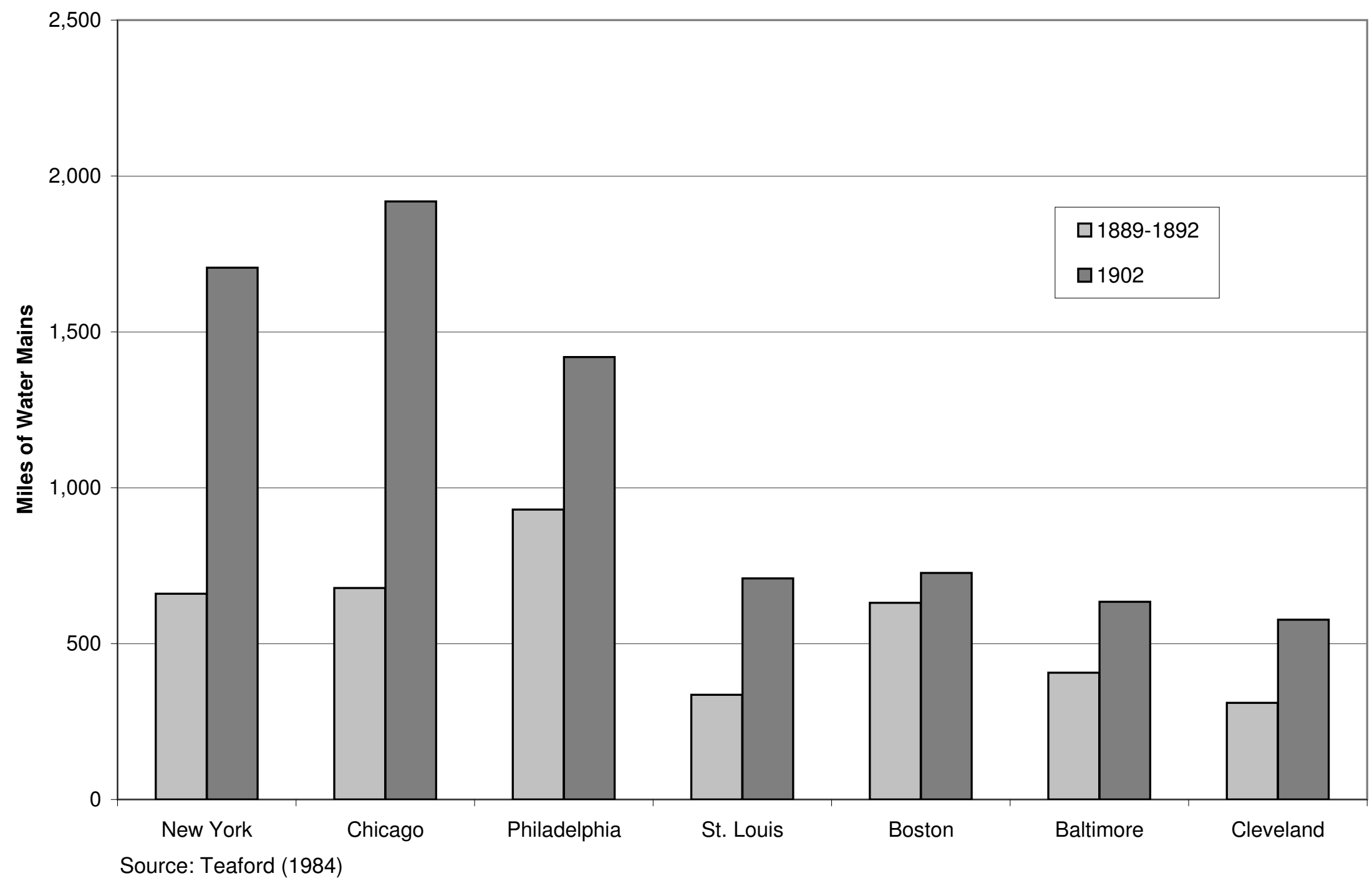


Figure 4: Per Capita Municipal Debt in the United States, 1843 to 1932 (in 2000 Dollars)

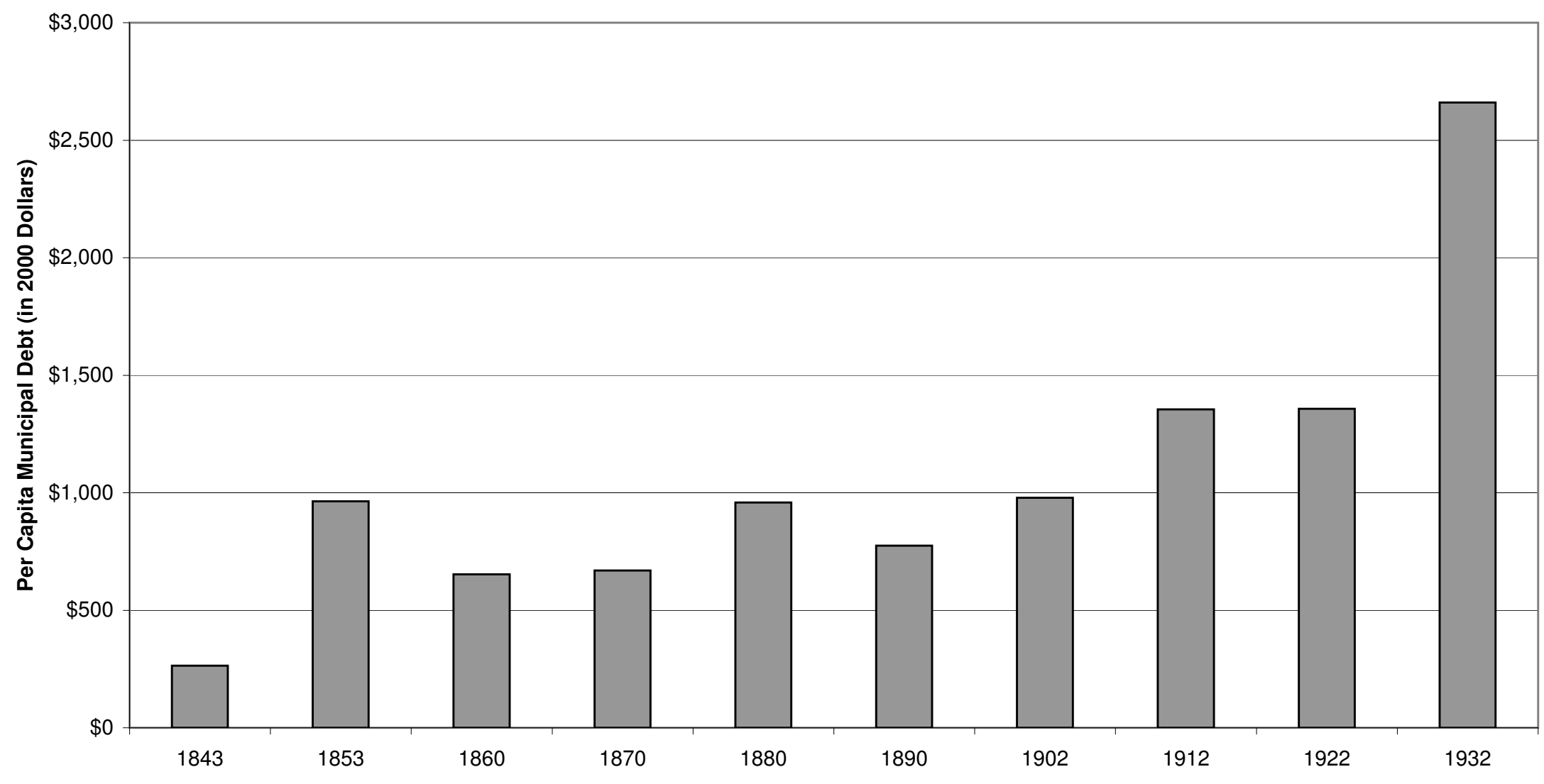

Source: Hillhouse (1936), historical census populations 1840-1940 (http://www.census.gov/population/censusdata/table-4.pdf), and authors' calculations 
Figure 5: Cumulative Share of Cities with Public Water Systems among Those with Public Systems in 1915 by Population and Decade

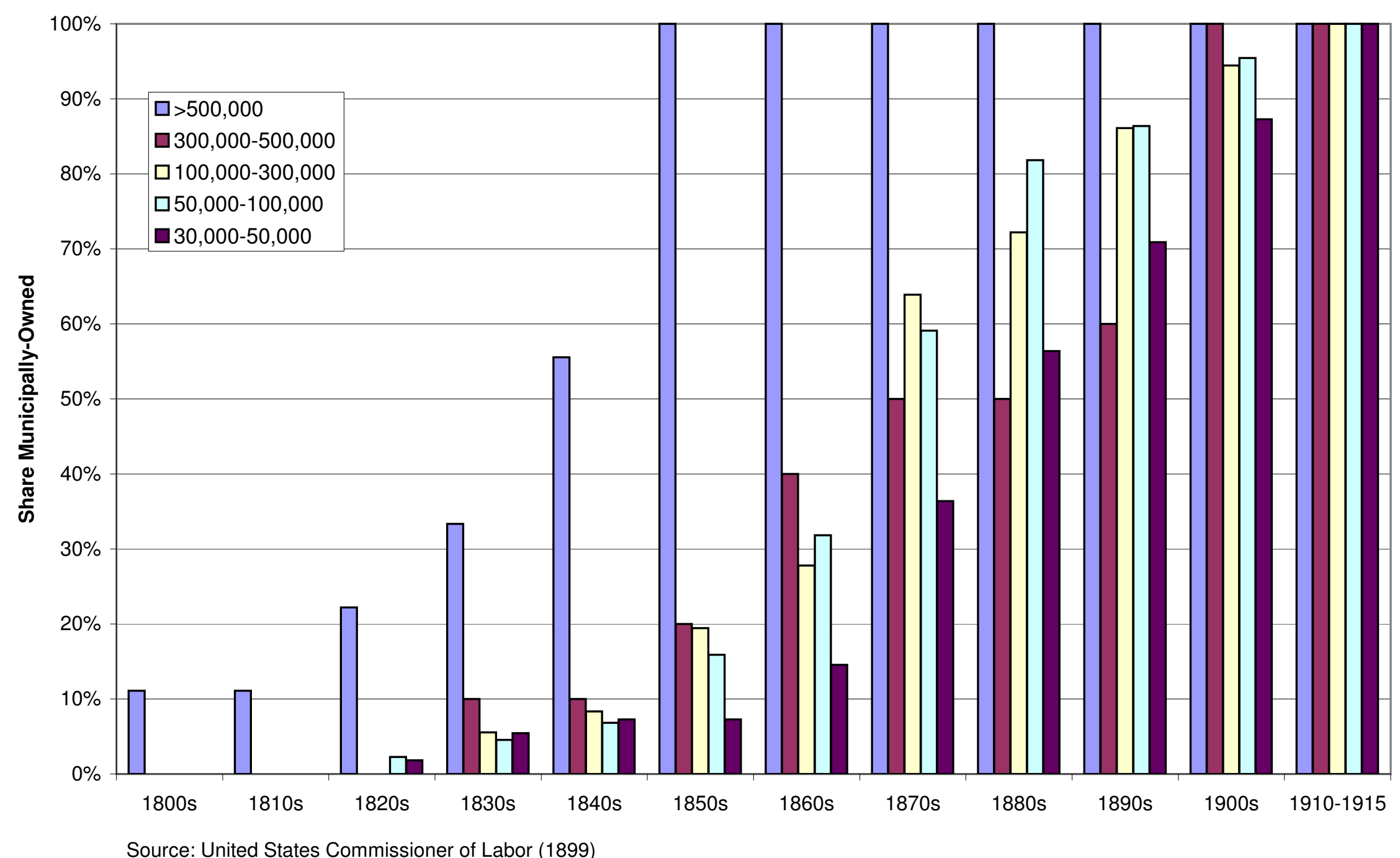


Figure 6: Mean Per Capita Debt, 1880-1902, by City Size in 1902

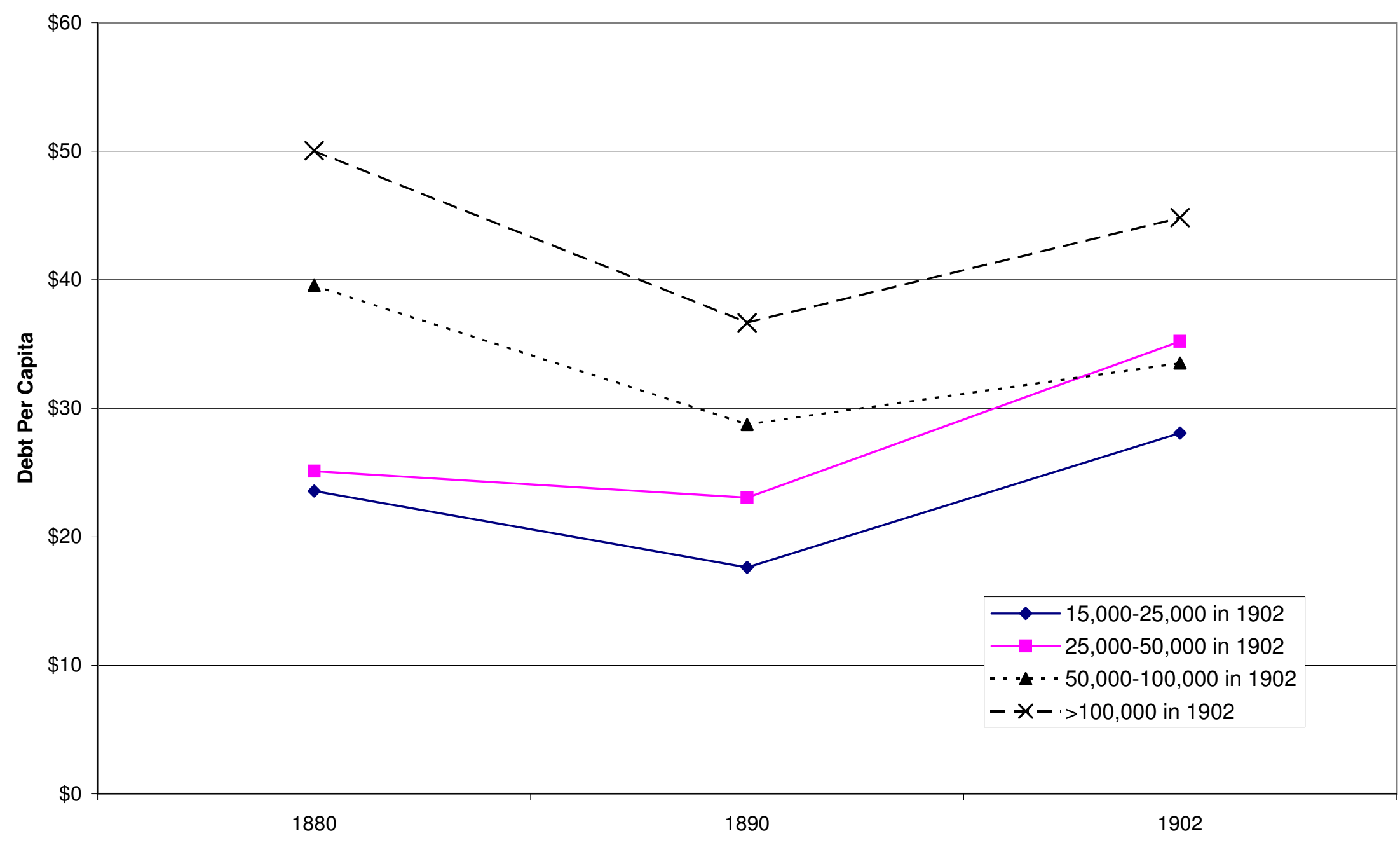

Source: United States Bureau of the Census (1907b) 
Figure 7: Percent Change in Mean Per Capita Debt, 1880-1902, by City Size in 1902

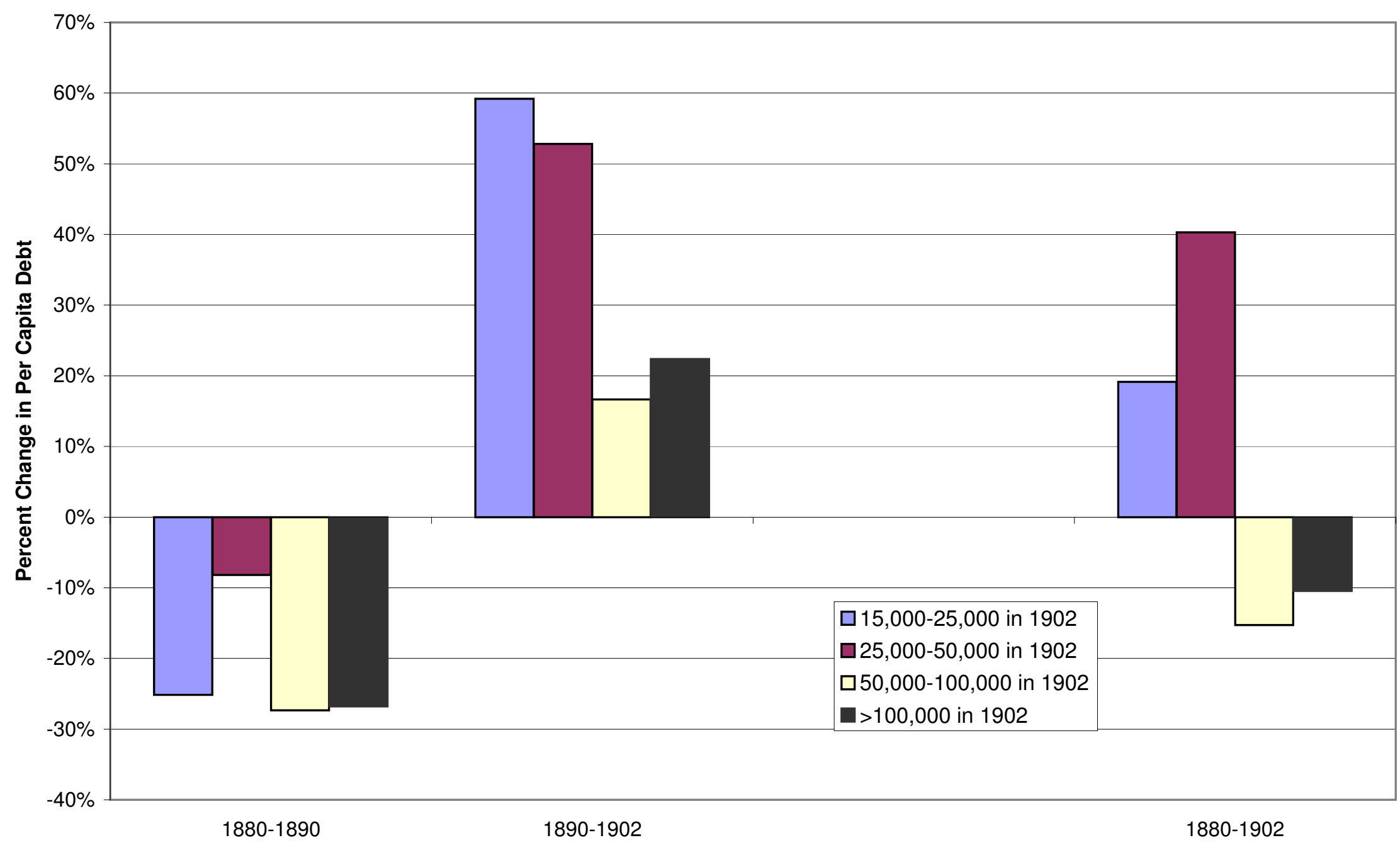

Source: United States Bureau of the Census (1907b) 
Figure 8: Nominal and Real Mean Annual Municipal Bond Yields in New England Cities, 1869-

1913

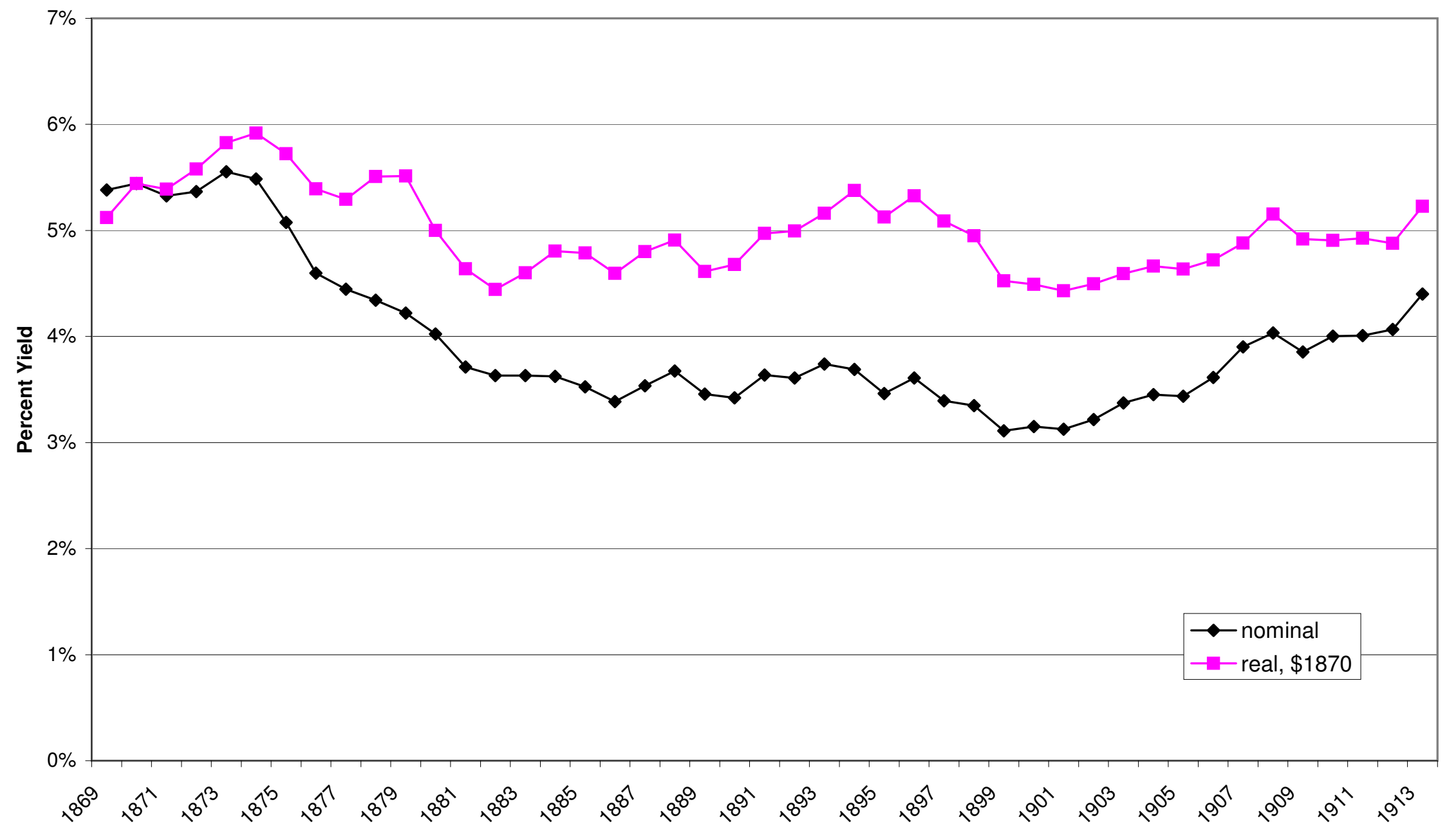

Source: NBER's Macro History Data Series \#13020; Balke and Gordon (1989) 